\title{
Gastrointestinal Parasitic Infection of Swamp Buffalo in Banten Province, Indonesia: Prevalence, Risk Factor, and Its Impact on Production Performance
}

\author{
N. Nurhidayah ${ }^{a}$, F. Satrija ${ }^{b, *}$, \& E.B. Retnani ${ }^{b}$ \\ aparasitology and Medical Entomology Study Program, Graduate School of Bogor Agricultural University \\ bepartment of Animal Infectious Disease and Veterinary Public Health, Faculty of Veterinary Medicine, \\ Bogor Agricultural University \\ Jalan Agatis, Kampus IPB Darmaga Bogor 16680, Indonesia \\ *Corresponding author: fsatrija@gmail.com \\ (Received 10-08-2018; Revised 17-11-2018; Accepted 31-12-2018)
}

\begin{abstract}
Gastrointestinal parasitic infections cause economic losses in large ruminant's production including swamp buffalo in tropical areas. The basic epidemiological data and impact of the infections in swamp buffaloes in Indonesia are very limited. A cross sectional study was conducted to measure the prevalence, to identify the risk factor, and to evaluate the impact of gastrointestinal parasites infection on production performance (BCS and girth) of swamp buffalo in five Sentra Peternakan Rakyat (SPR) in Banten Province, Indonesia. A total of 340 fecal samples were collected and examined microscopically using modified McMaster technique. The risk factors scrutinized in this study were sex, age, farming managements, and agroclimate. Infection was found in 128 buffaloes $(37.65 \%)$ consisted of Nematodes, i.e. Toxocara $(0.88 \%)$, Strongyles $(8.24 \%)$, Trichuris $(5.29 \%)$, Strongyloides $(2.94 \%)$, and Coccidia of Eimeria (30\%). Age of buffaloes was the only significant risk factor for the infection. The highest infection rate was occurred in the group of pre-weaned calves $(63.83 \%)$ and the lowest was found in the adults $(29.66 \%)$. Pre-weaned calve group was 8.519 and 8.435 times more likely to be infected with nematodes and protozoa, respectively. The Spearman correlation test showed that the girth was negatively low-correlated and significantly to the EPG of Toxocara vitulorum, the number of protozoa oocyst as well as the prevalence of gastrointestinal parasitic infections. BCS was not related to the infections. In conclusion, low prevalence of gastrointestinal parasitic infections potentially reduce the production performance of swamp buffaloes in the SPRs of Banten Province, Indonesia.
\end{abstract}

Keywords: gastrointestinal parasites; Indonesia; Sentra Peternakan Rakyat; swamp buffalo

\section{INTRODUCTION}

Gastrointestinal parasitic infections are recognized as one of the major obstacles in profitable large ruminant production in subtropical and tropical countries including Indonesia. The parasites cause considerable economic losses due to: (1) animal health disorders as direct effects of parasite infection in the gastrointestinal tract (e.g. weakness, diarhea, anorexia, anemia, intestinal obstruction, etc.), and indirect effects which may manifest as an increasing susceptibility to secondary infection (Hendawy, 2018; Van Der Steen et al., 2014), (2) reduce livestock productivity as indicated by a slower growth rate, low milk production, low body condition score (BCS), and the fatality in young animals (Fitzpatrick, 2013), as well as (3) additional therapeutic cost (Charlier et al., 2015).

In attempt to improve buffalo production, Ministry of Agriculture, the Republic of Indonesia has established a Sentra Peternakan Rakyat/SPR program as a center for the development of buffalo community farming in Banten Province. For centuries, swamp buffaloes
(Bubalus bubalis) have been raised by most of South-east Asian farmers mainly as drought animals in paddy field, source of meat, and family saving (Pasha \& Hayat, 2012). Yet, swamp buffaloes remained kept under a traditional small-holder farming system like in most of South-East Asian countries. This traditional farming system is typically characterized by the traditional farming methods with lack of capital and access to resources including animal health service and training for farmers (Gayatri \& Vaarst, 2015; Rast et al., 2014). Indonesia's tropical climatic conditions create an ideal environment for gastrointestinal parasite development and transmission in the field. These combinations aggravate the risk of nematodosis and other gastrointestinal parasitic infections.

Studies on gastrointestinal parasite infections of buffaloes in Indonesia are still limited. Satrija et al. (2011) identify that Toxocara vitulorum is the most prevalent and highly pathogenic nematode infecting buffalo calves in the early months of their lifes. Recent explorative study found Moniezia (Cestode) and eight genera of Nematode (Toxocara, Strongyloides, 
Capillaria, Haemonchus, Trichostrongylus, Cooperia, Oesophagostomum, and Bunostomum) parasitized gastrointestinal tract of buffaloes in several locations in the Java and Lombok Islands. The prevalences of the cestode and nematode infections were ranged between $2.7 \%$ and $17.2 \%$ and $40.5 \%$ and $82.7 \%$, respectively (Karim et al., 2016) However, no data are available on the prevalence, risk factors, and impact on production performance of gastrointestinal parasitic infections in swamp buffaloes in Sentra Peternakan Rakyat (SPR) of Banten Province. These informations are required to determine the disease's importance and as a basis for its control strategies.

\section{MATERIALS AND METHODS}

\section{Ethical Approval}

All procedures in this study were approved by the Animal Use Ethical Committee of Bogor Agricultural University (Approval Letter number 65-2017 IPB).

\section{Study Area}

A study with cross sectional design was conducted from March to May 2017 at five Sentra Peternakan Rakyat (SPRs) in Banten Province, Indonesia. The SPRs were located in two districts, i.e., Serang (SPR Harapan Manis) and Lebak (SPR Cipanas, SPR Sejahtera Bersama, SPR Bina Makmur, and SPR Munding Pakidulan). The latitude of each SPR location was determined using the Global Positioning System (GPS) GARMIN® 64S locator. Coordinate measurements were carried out with a maximum distance of 5 meters from the sampling points. In general, the people of Banten Province use swamp buffaloes as meat producers, working animals for draught, meat and fertiliser producers as well as an asset for saving or investment purposes. The buffaloes were managed communally in small group (1-20 heads) with various traditional management systems. In the first system, the buffaloes were free-grazed in the forest all year with a very limited intervention of feed and medication. In the second system, the buffaloes were grazed in several-mixed locations including forest, paddy-field (harvest times), and rubber-stock farm. In the third system, in a very small number of farmers, they practiced an intensive farming management where the buffaloes were only fed using grass and or rice-straw from cut and carry method. The wallow was naturally available around the habitat or being provided by the farmers to let the buffaloes express their natural behaviors since buffaloes are categorized as swamp animals.

\section{Collection and Examination of Fecal Samples}

A total of 340 fecal samples were randomly collected from swamp buffaloes in five SPRs. The collection of the samples were done rectally and then transported to the laboratory using cool box. Each fecal sample was examined quantitatively using a Modified McMaster technique (Taylor et al., 2016). Four grams of fecal samples were measured, added with flotation solution and filtered several times. One milliliter of these solution was pippeted into McMaster chamber (FHK, Japan) and examined microscopically (100 magnifications). This method is useful to identify the presence of parasites and quantify the intensities of Nematode, Cestode, and parasitic protozoan infections. The identification procedure of gastrointestinal parasite's egg and protozoan's oocyst were performed according to the identification guideline of Taylor et al. (2016). The intensity of infection was noted as egg per gram (EPG) for each type of egg and oocyst per gram (OPG) for parasitic protozoan found in fecal examination.

Fecal samples having Strongyle eggs from each SPR were pooled and subjected to fecal culture. Thus a pooled of 10-50 gram of moist feces was mixed throughly with vermiculite (1:3) in a plastic tray. The feces-vermiculite mixture was left for 7-10 days at room temperature and stirred once a day to give a good aeration. After 7 days, strongyle infective larvae (L3) were collected using sedimentation glasses. The L3 were microscopically identified to genus level using Van Wyk \& Mayhew (2013) identification key.

\section{Questioners}

The structured-questioner was given to 169 respondents (buffaloes-owners or stockman) to collect data on risk factors of gastrointestinal parasitic infection. Questions included farmers and farming profile as well as livestock's signalments and managements (cage, feeding, and medical record).

\section{Agroclimatological Parameters}

Data of agroclimatological parameters consisted of temperature, humidity, and precipitation observations in the study area were obtained from Pondok Betung Climatological Station in South Tangerang, Banten Province. Agroclimatological data and results of GPS reading were subsequently extrapolated with map of Oldeman's agroclimate tipology 2006-2016 (BMKG, 2017) to determine the type of agro-climate for each SPR location.

\section{Production Performance Aspect}

The measurement of production aspects including body girth was done using ANIMETER ${ }^{\circ}$ (Germany), while Body Condition Scores (BCS) were recorded according to Anitha et al. (2011). The scores were then recorded for each animal in each location.

\section{Statistical Analysis}

The prevalence, EPG, and OPG were performed descriptively as table and or graphic. Identification analysis for risk factor of infection was done by chi-square test and followed by multiple binary logistic analysis in SPSS v.22. Spearman correlation analysis was used to correlate parasitic parameters (prevalence and intensity) to production performance (BCS and girth). 


\section{RESULTS}

Microscopic examination showed that 128 (37.65\%) of swamp buffaloes from five SPRs were infected with Nematodes and Coccidian protozoa (Genus Eimeria). The prevalence for each group observed was as follow: Nematodes $(15 \%)$ and coccidian protozoa $(30 \%)$, respectively. There were 4 Nematode egg types found i.e., Toxocara $(0.88 \%)$, strongyle $(8.24 \%)$, Trichuris $(5.29 \%)$, and Strongyloides $(2.94 \%)$. These findings were followed by fecal egg counts (FECs) results presented in Table 1. The highest mean EPG was observed in strongyles, followed by Trichuris, Strongyloides, and Toxocara. Additionally, the number of protozoan oocyst found were 932 oocysts per gram of fecal sample. No Cestode egg was found in all samples.

However, unexpected result was observed in the process of culturing fecal samples. No infective larvae (L3) of Nematode was found, which makes the identification of Strongyles' eggs found in the fecal samples could not be conducted.

A consistent pattern was observed on each categories for both infections (nematodosis and parasitic protozoa) (Figure 1). Infection of gastrointestinal parasites was mostly occurred in male buffaloes (53.7\%) than in females buffaloes (34.62\%). Prevalence based on age

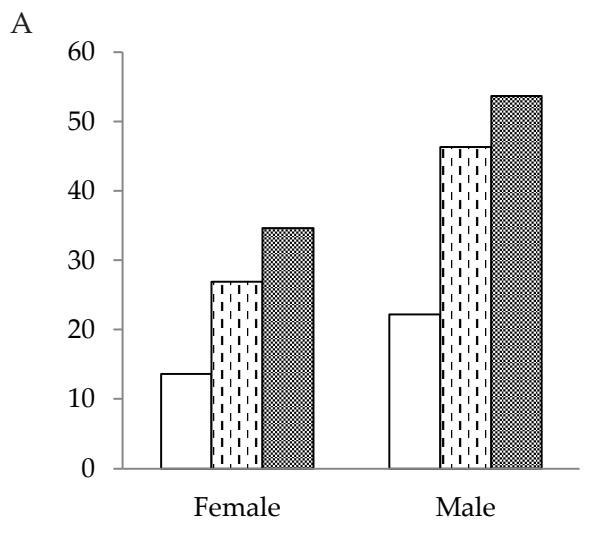

$\square$ Nematodes $\square$ Protozoa $\mathbf{0}$ GI Parasites

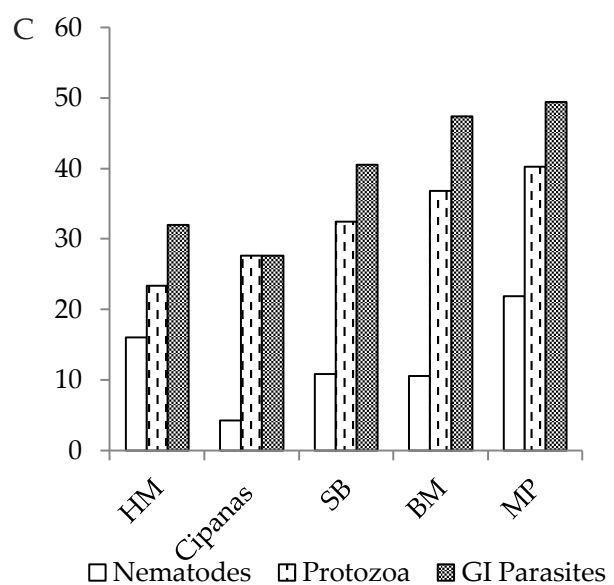

showed a clear age-dependent pattern in which high value was found in pre-weaned calve (0-8 months) and continue to decrease in calves ( $>8-18$ months), youngs (>18-32 months) to adults (>32 months). The highest infection based on SPR location was in SPR Munding Pakidulan with 43 swamp buffaloes infected (49.43\%). Infection prevalence for SPR Harapan Manis, SPR Cipanas, SPR Sejahtera Bersama, and SPR Bina Makmur were $32 \%, 27.66 \%, 40.54 \%$, and $47.37 \%$, respectively. Infection prevalences viewed from agroclimatological condition were B2 (44.12\%), C1 (31.43\%), C2 (28.57\%), and C3 (36.28\%).

Tables 1. Fecal examination result of 340 swamp buffaloes in SPRs located in Banten Province using modified McMaster technique

\begin{tabular}{lccr}
\hline \multicolumn{1}{c}{ Parasites } & $\begin{array}{c}\text { Positive } \\
\text { samples }\end{array}$ & $\begin{array}{c}\text { Prevalence } \\
(\%)\end{array}$ & Mean EPG \\
\hline Nematode & & & \\
Toxocara & 3 & 0.88 & $83.33 \pm 57.74$ \\
Strongyles & 28 & 8.24 & $117.86 \pm 72.28$ \\
Trichuris & 18 & 5.29 & $147.22 \pm 110.44$ \\
Strongyloides & 9 & 2.94 & $160.00 \pm 281.66$ \\
Protozoan oocyst & 102 & 30.00 & $932.00 \pm 21.14$ \\
\hline
\end{tabular}
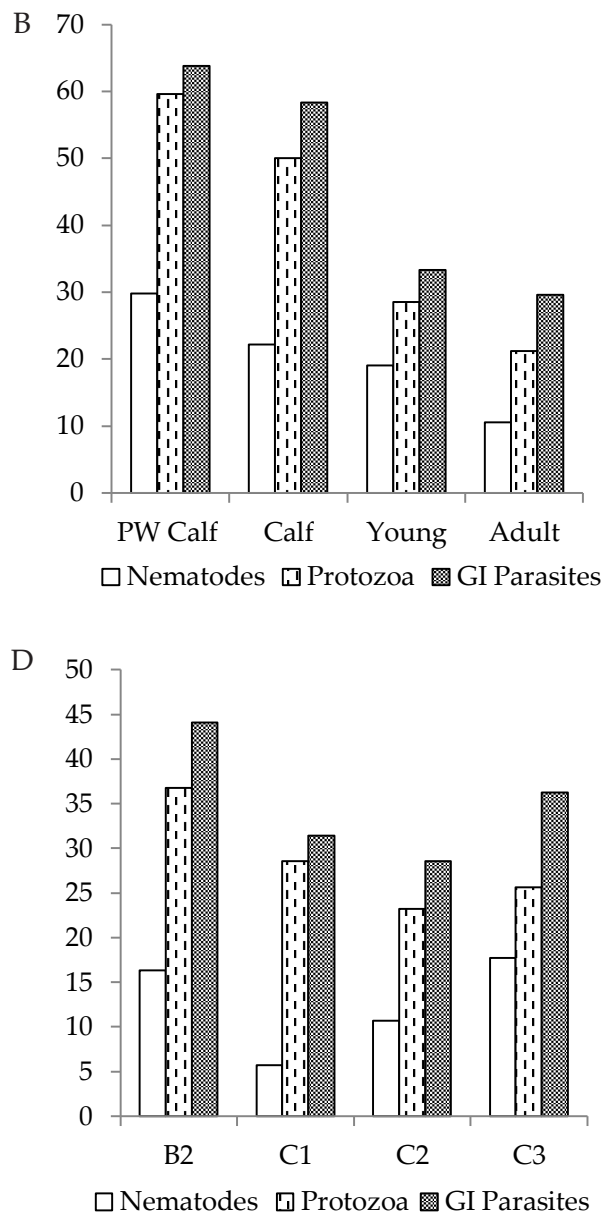

Figure 1. Prevalence of gastrointestinal parasites (\%) based on several categories: (A) sex; (B) age group; (C) SPR location (HM= SPR Harapan Manis, SB= SPR Sejahtera Bersama, SB= SPR Bina Makmur, MP= SPR Munding Pakidulan); and (D) agroclimatological condition (B2=7-9 wet months with 2 -4 dry months, C1 $=5-6$ wet months with $<2$ dry months, C2 $=5-6$ wet months with $2-4$ dry months, C3= both of wet and dry months were equals $5-6$ months. 
During indepth interview approach, there were 20 variables as candidates of risk infection factors. The selection of these candicates was done by chi-square test, those which resulted in significant value to Nematode infection $(\mathrm{P}<0.05)$ such as age, communal cage of preweaned calves and adults, as well as irregular medical check up. On the other hand, infection by protozoa was also related to sex and age as well as irregular body cleaning and agroclimatic condition of SPR locations $(\mathrm{P}<0.05)$ (Table 2).

The risk factor analysis was continued to multivariate analysis through binary logistic regression (Table 3). It could be seen that age of buffaloe was the only significant risk factor for both infection (nematodosis p-value 0.002 and infection of coccidian protozoa p-value 0.001 ). In nematodosis, the odd ratio number of pre-weaned calve group was 8.519. It could be interpreted that the group of pre-weaning calves was 8.519 times had higher risk to nematodosis compared to the adult group as a reference. As was found in another group, the risk factor analysis also showed that young and calves had 2.556 and 2.190 times higher risk to nematodes compared to adult buffaloes. On the other hand, risk factor for coccidian protozoa infection was also found the highest in the pre-weaning (OR 8.435), followed by calves (1.807), young (1.406), and adult buffaloes (as a reference). These mean the group of pre-weaning calves (0-8 months) has the highest infection risk for both nematodosis and coccidian protozoas.
Coefficient correlation of production parameters (BCS and girth), prevalence and EPG of gastrointestinal parasite infection showed the interesting findings (Table 4 ). The results could be interpreted by comparing the coefficient correlation number to the following criterias: very low (coefficient correlation 0.00-0.19), low (0.2-0.39), middle (0.4-0.59), high (0.6-0.79), and very high $(0.8-1)$. Low-positive significant correlation was observed between BCS and girth. Various negative correlations were seen for BCS to the other parameters, but only the OPG and gastrointestinal parasite prevalence that had low-significance and negatively correlated to the BCS $(\mathrm{P}<0.05)$. It meant that an increase in OPG and gastrointestinal parasites would be followed with a decrease in BCS in relatively low level. Very low to low negative significance was found in the correlation of girth to EPGs, OPG, and gastrointestinal parasite prevalence. The girth was very low-negative-significantly correlated to EPG of Toxocara (coefficient correlation -0.176; $\mathrm{P}<0.01$ ) and low-negative-significantly correlated to OPG (coefficient correlation of -0.432 ; $\mathrm{P}<0.05$ ) and gastrointestinal parasite prevalenve (coefficient correlation of $-0.325 ; \mathrm{P}<0.05)$. On the other hand, EPGs of most gastrointestinal helminthes (Strongyle, Trichuris, and Strongyloides) and OPG had a positive correlation to the prevalence of gastrointestinal parasites, although the significance was not observed for the EPG of T. vitulorum. This could be interpreted that a low prevalence and or intensity of T. vitulorum in buffaloes was able to

Table 2. Chi-square analysis for candidates of risk factors related to gastrointestinal parasite infections in swamp buffalo in SPR located in Banten Province, Indonesia

\begin{tabular}{|c|c|c|c|c|c|c|}
\hline \multirow[b]{2}{*}{ Variables } & \multicolumn{3}{|c|}{ Nematodosis } & \multicolumn{3}{|c|}{ Protozoa } \\
\hline & $\begin{array}{c}\text { Number of } \\
\text { infected buffaloes } \\
(n=28)\end{array}$ & $\begin{array}{l}\text { Number of unin- } \\
\text { fected buffaloes } \\
(n=141)\end{array}$ & $\mathrm{P}$-value & $\begin{array}{c}\text { Number of } \\
\text { infected buffaloes } \\
(n=45)\end{array}$ & $\begin{array}{l}\text { Number of unin- } \\
\text { fected buffaloes } \\
\quad(\mathrm{n}=124)\end{array}$ & P-value \\
\hline Sex & & & 0.116 & & & $0.025^{a}$ \\
\hline Male & 8 & 17 & & 12 & 13 & \\
\hline Female & 20 & 124 & & 33 & 111 & \\
\hline Age & & & $0.000^{\mathrm{a}}$ & & & $0.000^{\mathrm{a}}$ \\
\hline Pre-weaned calve & 10 & 11 & & 14 & 7 & \\
\hline Calve & 4 & 16 & & 6 & 14 & \\
\hline Young & 2 & 6 & & 2 & 6 & \\
\hline Adult & 12 & 108 & & 23 & 97 & \\
\hline Communal housing & & & $0.034^{\mathrm{a}}$ & & & 0.367 \\
\hline Yes & 0 & 20 & & 7 & 13 & \\
\hline No & 28 & 121 & & 38 & 111 & \\
\hline Daily body cleaning & & & 0.810 & & & $0.039^{a}$ \\
\hline Yes & 12 & 129 & & 38 & 117 & \\
\hline No & 2 & 26 & & 7 & 7 & \\
\hline Animal health check up & & & $0.033^{\mathrm{a}}$ & & & 0.280 \\
\hline Yes, routine & 18 & 84 & & 45 & 71 & \\
\hline Seldom & 10 & 57 & & 14 & 53 & \\
\hline Agroclimatic type & & & 0.055 & & & $0.047^{a}$ \\
\hline B2 & 18 & 65 & & 27 & 56 & \\
\hline $\mathrm{C} 1$ & 0 & 8 & & 4 & 4 & \\
\hline $\mathrm{C} 2$ & 0 & 22 & & 2 & 20 & \\
\hline C3 & 10 & 46 & & 12 & 44 & \\
\hline
\end{tabular}

Note: B2=7-9 wet months with 2-4 dry months, C1= 5-6 wet months with $<2$ dry months, C2= 5-6 wet months with $2-4$ dry months, C3= both of wet and dry months were equals 5-6 months. 
Table 3. Result of multivariate analysis for risk factor analysis for gastrointestinal parasite infection in swamp buffalo in SPR of Banten Province, Indonesia

\begin{tabular}{llcccc}
\hline \multirow{2}{*}{ Parasites } & \multicolumn{1}{c}{ Factors } & Significant & Odd ratio & $\begin{array}{c}\text { Confidence inter- } \\
\text { val (95\%) }\end{array}$ & P-value \\
\hline Nematodes & Age & & & & 0.002 \\
& Pre-weaning calve & 0.000 & 8.519 & $2.884-25.159$ & $0.619-7.750$ \\
& Calve & 0.224 & 2.190 & $0.462-14.124$ \\
\multirow{2}{*}{ Protozoa } & Young & 0.282 & 2.556 & & 0.001 \\
& Adult & & Reference & & \\
& Age & & & & \\
& Pre-weaning calve & 0.000 & 8.435 & $0.627-5.211$ & \\
& Calve & 0.273 & 1.807 & $0.266-7.420$ & \\
\hline
\end{tabular}

Table 4. Result of Spearman correlation analysis between gastrointestinal parasite infection (prevalence and intensity) and the production performance of swamp buffaloes in SPR of Banten Province, Indonesia

\begin{tabular}{|c|c|c|c|c|c|c|c|c|c|}
\hline & & \multirow{2}{*}{ BCS } & \multirow{2}{*}{ Girth } & \multicolumn{4}{|c|}{ EPG } & \multirow{2}{*}{$\begin{array}{l}\text { OPG } \\
\text { Ook }\end{array}$} & \multirow{2}{*}{$\mathrm{P}$} \\
\hline & & & & Tox & StrL & Tric & StDes & & \\
\hline BCS & & 1.000 & $0.394^{a}$ & -0.075 & -0.057 & -0.029 & -0.073 & $-0.374^{\mathrm{a}}$ & $-0.233^{a}$ \\
\hline Girth & & $0.394^{\mathrm{a}}$ & 1.000 & $-0.176^{b}$ & -0.166 & -0.100 & -0.150 & $-0.432 a$ & $-0.325^{a}$ \\
\hline \multirow[t]{4}{*}{ EPG } & Tox & -0.075 & $-0.176^{\mathrm{b}}$ & 1.000 & 0.135 & $0.273^{a}$ & -0.044 & 0.111 & 0.174 \\
\hline & StrL & -0.057 & -0.166 & 0.135 & 1.000 & 0.107 & $0.321^{\mathrm{a}}$ & 0.098 & $0.361^{\mathrm{a}}$ \\
\hline & Tric & -0.029 & -0.100 & $0.273^{a}$ & 0.107 & 1.000 & -0.051 & 0.041 & $0.202^{\mathrm{b}}$ \\
\hline & StDes & -0.073 & -0.150 & -0.044 & $0.321^{a}$ & -0.051 & 1.000 & 0.121 & $0.309^{a}$ \\
\hline OPG & Ook & $-0.374^{a}$ & $-0.432^{a}$ & 0.111 & 0.098 & 0.041 & 0.121 & 1.000 & $0.806^{\mathrm{a}}$ \\
\hline $\mathrm{P}$ & & $-0.233^{a}$ & $-0.325^{a}$ & 0.174 & $0.361^{a}$ & $0.202^{b}$ & $0.309^{a}$ & $0.806^{a}$ & 1.000 \\
\hline
\end{tabular}

Note: $a=$ Correlation is significant at 0.01 level (2-tailed); $\mathrm{b}=$ Correlation is significant at 0.05 level (2-tailed); $\mathrm{BCS}=$ Body condition scoring; EPG= egg per gram fecal sample; $\mathrm{OPG}=$ Oocyst per gram fecal sample; $\mathrm{P}=$ prevalence of gastrointestinal parasites.

decrease production performance if measured by body girth of animal.

\section{DISCUSSION}

The results of this cross-sectional study were in line with those of previous studies of Nematode infection in buffaloes in Asian countries (Khan et al., 2010; Mamun et al., 2011; Karim et al., 2016). In general, both prevalence and parasitic burden were low indicating a subclinical infection. Strongyles became the most prevalent Nematodes found during the microscopic examination. It could be easily identified from the grape-shaped embrios inside an oval-shape-egg which may belong to Haemonchus, Ostertagia, Trichostrongylus, Mecistocirrus, Cooperia, Nematodirus, Oesophagostomum, Chabertia, and Bunostomum. Most species of Strongyles were cosmopolitant and often found in small and large ruminants.

However, genus identification for Strongyles could not be conducted in this study due to the absence of the third stage larvae (L3) during the coproculture process. Normally, a suitable culture might result in the recovery of $50 \%$ of eggs in the faeces as well as the third stage of larvae (L3) (Ministry of Agriculture, Fisheries and Food of England, 1986). Although the positive fecal samples had been pooled, the very low number of EPG was not enough to provide L3 in coproculture process (Table 1). Another type of eggs found in the fecal examination was
Toxocara type. Most of previous report mentioned that T. vitulorum was a major Ascaridae infecting buffaloes around the world (Satrija et al., 2011; Taylor et al., 2016). This study also found Trichuris and Strongyloides eggs that were probably two species of Trichuris (i.e. T. globulosa dan T. discolor) and S. papillosus (Taylor et al., 2016).

The prevalence based on sex category implied that infection in male was slightly higher than in female group, but the correlation between both sexes was not significant $(P>0.001)$ (Figure 1A). Similar findings were observed in buffaloes (Karim et al., 2016) and small ruminants (Tariq et al., 2010). Both sexes were equally susceptible and strongly influenced by management condition of animal host (Tariq et al., 2010). Female animals became more susceptible to infection due to pregnancy and parturition, while the higher infection in male was related to its role as working animal which increases the exposure time to infective stage in the environment (Taylor et al., 2016).

Infection based on age group clearly showed the age-dependent pattern. The highest number of infection was found in the group of pre-weaned calves (0-8 months) and continuously decrease with age. The result of multiple logistic regression showed a significant relation between pre-weaned calves group and both parasite infections (nematodosis and protozoan). Previous study by Karim et al. (2016) showed that Strongyle's infection in cattle and buffalo was higher in 
calves group of both animals. The EPGs were high in calves and counted very low in adult group. Dorny et al. (2010) also mentioned the same pattern in cattles in Cambodia during longitudinal study. Calves or young animals had a higher prevalence and excreted more $T$. vitulorum's eggs compared to adult group. Undeveloped immune system of buffalo calves might be related to this phenomenon. In a very early age, the ruminant received native immunity from colostrums, while the mucosal surface provided non-specific immunity (such as natural killer cell, macrophages, activated mediators of enzymes and complements). In advanced protection to most of gastrointestinal nematodes infection, T-helper 2 cytokines drive the effector cells including eosinophils and mast cells. T2 secreted interleukins (IL3, IL-4, IL-5, IL-9, IL-10, and IL-13) and B-Cell developed immunoglobulins (IgA, IgE, and $\operatorname{IgG})$. In most of ruminant, their lymphoid organs are fully functional after weaning period (Hendawy, 2018).

Five SPRs were located on areas with varied agroclimatic conditions based on the recent data of Oldeman climate classification 2006-2016 (BMKG 2017). Since the infection of gastrointestinal parasites were affected by the climate component (i.e temperature, rainfall, humidity, etc) and several SPRs also shared several climate types, analysis based on climate types was required. There were four types of climates i.e., B2 (7-9 wet months with 2-4 dry months), C1 (5-6 wet months with $<2$ dry months), C2 (5-6 wet months with 2-4 dry months), and C3 (both of wet and dry months were equals 5-6 months). Wet and dry months were distinguished by rainfall intensity of $100-200 \mathrm{~mm} / \mathrm{month}$ and $<100 \mathrm{~mm} /$ month, respectively.

The result showed that gastrointestinal parasites was most prevalent in C3 area and slightly lower in B2. Those areas are classified as two wet areas with medium to high intensity of rainfall within a year. Freeliving stages of parasites need suitable microhabitats for their developments and survivals. This might be affected by some environmental factors such as humidity, temperature, rainfall, soil structure, and vegetation type. Warm and wet environmental condition as well as adequate moisture and temperature in some tropical areas provide a suitable condition for Nematodes infective stage development, whereas dessication due to the lack of rainfall kills eggs and larvae rapidly. Soil type influenced the growth while the composition of folliage species affected the moisture and humidity, storing moisture and perfect humidity even after several weeks in drough. Although there are slow climate changes occurring in recent years, parasites survive every year in some tropical areas. There are periods of times when a condition is suitable for parasitic development and survival. The development of a large number of infective stage of parasites within a certain season will be followed by a high mortality rate (one to several weeks) (Taylor et al., 2016). The concept of integrated cropcattle farming system by Munandar et al. (2015) should be considered in the level of SPR in Banten Province. Processed fecal materials from swamp buffaloes can be used as an organic fertilizer for crop as well as eliminator of parasites during their pre-parasitic stages.

In this study, we also provide correlation data for gastrointestinal infection and its impact. Two main indicators of production parameters (BCS and girth) were observed and analized statistically. Low-positive significant correlation was observed between BCS and girth. It means that an increase of girth will be followed by an increase of BCS in a low level. Although both production parameters were negatively-low correlated to gastrointestinal parasites' prevalence and their intensities as well, the low-negative and significant correlation was only observed in the correlation between girth and EPG of T. vitulorum $(\mathrm{P}<0.001)$. This finding indicated that low infection of T. vitulorum was enough to affect the girth of buffaloes. The parasites might be present in small intestine and cause a health disorder including poor performance, colic, abdominal distension and obstruction, and fatality (Van Der Steen et al., 2014). Young animal might be infected and the egg output can be very high (>50 000 EPG) (Taylor et al., 2016). Further, all positive correlations observed between prevalence to its EPGs and OPG of gastrointestinal parasites proved that the method we used was accurate. Detection of egg found in the fecal sample using Mc Master technique is cheap, simple, and accurate (Taylor et al., 2016).

\section{CONCLUSION}

Swamp buffaloes in Sentra Peternakan Rakyat (SPR) of Banten Province were infected by 4 Nematodes (Toxocara vitulorum, Strongyles, Trichuris, and Strongyloides) and coccidian oocyst of parasitic protozoans (Genus Eimeria) with a total prevalence of $37.65 \%$. Age was found to be the main risk factor of infection. It has been proven that infection of gastrointestinal parasites give a negative significant correlation to production performance shown by the low-negative significant coefficient correlation between prevalence to BCS and girth. Only EPG of T. vitulorum and the number of oocyst were significant to girth, which means infection by helminth (T. vitulorum) and parasitic protozoan would significantly affect the production performance of buffaloes.

\section{CONFLICT OF INTEREST}

There is no conflict of interest with any financial, personal, or other relationships with other people or organizations related to this work.

\section{ACKNOWLEDGEMENT}

This study was supported by PMDSU Scholarship from the Ministry of Research, Technology and Higher Education (Kemenristek DIKTI), Indonesia (Grant number: 330/SP2H/LT/DRPM/IX/2016). We are grateful to the SPRs' members, the Livestock Services of Serang and Lebak Districs, and FVM IPB students for their helps during sampling and laboratory analyses. 


\section{REFERENCES}

Anitha, A., K. Sarjan Rao, J. Suresh, P. R. Srinivasa Moorthy, \& Y. Kotilinga Reddy. 2011. A body condition score (BCS) system in Murrah buffaloes. Buffalo Bull. 30:79-99.

BMKG (Meteorological, Climatological and Biophysical Agency). 2017. Oldeman Climate Classification Map 20062016. Pondok Betung Climate Station, Tangerang Selatan.

Charlier, J., F. V. Velde, M. Van Der Voort, J. V. Meensel, L. Lauwers, V. Cauberghe, J. Vercruysse, \& E. Claerebout. 2015. Econohealth: Placing helminth infections of livestock in an economic and social context. Vet. Parasitol. 212:6267. https://doi.org/10.1016/j.vetpar.2015.06.018

Dorny, P., V. Stoliaroff, J. Charlier, S. Meas, S. Sorn, B. Chea, D. Holl, D. Van Aken, \& J. Vercruysse. 2010. Infections with gastrointestinal nematodes, Fasciola and Paramphistomum in cattle in Cambodia and their association with morbidity parameters. Vet. Parasitol. 175:293-299. https://doi. org/10.1016/j.vetpar.2010.10.023

Fitzpatrick, J. L. 2013. Global food security: the impact of veterinary parasites and parasitologists. Vet. Parasitol. 195:233-248. https://doi.org/10.1016/j.vetpar.2013.04.005

Gayatri, S. \& M. Vaarst. 2015. The implementation of Indonesia's beef self-sufficiency programme (BSSP) as seen from a farmer-family perspective. J. Rural Community Dev. 10:166-186.

Hendawy, S. H. M. 2018. Immunity to gastrointestinal nematodes in ruminants: effector cell mechanisms and cytokines. J. Parasit. Dis. 42:471-482. https://doi.org/10.1007/ s12639-018-1023-x

Karim W., A. Farajallah, \& B. Suryobroto. 2016. Exploration and prevalence of gastrointestinal worm in buffalo from West Java, Central Java, East Java and Lombok, Indonesia. Aceh J. Anim. Sci. 1:1-15. https://doi.org/10.13170/ ajas.1.1.3566

Khan, M. N., M. S. Sajid, M. K. Khan, Z. Iqbal, \& A. Hussain. 2010. Gastrointestinal helminthiasis: prevalence and associated determinants in domestic ruminants of district Toba Tek Singh, Punjab, Pakistan. Parasitol. Res. 107:787-794. https://doi.org/10.1007/s00436-010-1931-x
Mamun, M. A. A., N. Begum, \& M. M. H. Mondal. 2011. A coprological survey of gastro-intestinal parasite of water buffaloes (Bubalus bubalis) in Kurigram district of Bangladesh. J. Bangladesh Agril. Univ. 9:103-109. https:// doi.org/10.3329/jbau.v9i1.8752

Ministry of Agriculture, Fisheries and Food of England. 1986. Manual of Veterinary Parasitological Laboratory Technique. Her Majesty's Stationary Office, London.

Munandar, F. Gustiar, Yakup, R. Hayati, \& A. L. Munawar. 2015. Crop-cattle integrated farming system: an alternative of climate change mitigation. Med. Pet. 38:95-103. https:// doi.org/10.5398/medpet.2015.38.2.95

Pasha, T. N., \& Z. Hayat. 2012. Present situation and future perspective of buffalo production in Asia. JAPS. 22:250-256.

Rast, L., J. L. M. L. Toribio, N. K. Dhand, S. Khounsy, \& P. A. Windsor. 2014. Why are simple control options for Toxocara vitulorum not being implemented by cattle and buffalo smallholder farmers in South-East Asia? Preventive Vet. Med. 113:211-218. https://doi.org/10.1016/j. prevetmed.2013.10.021

Satrija, F., Y. Ridwan, \& E.B. Retnani. 2011. Efficacy of piperazine dihydrochloride against Toxocara vitulorum in buffalo calves. J.Vet.12:77-82

Tariq, K. A., M. Z. Chishti, \& F. Ahmad. 2010. Gastrointestinal nematode infections in goats relative to season, host, sex and age from the Kashmir valley, India. J. Helminthol. 84:93-97. https://doi.org/10.1017/S0022149X09990113

Taylor, M. A., R. L. Coop, \& R. L. Wall. 2016. Veterinary Parasitology: $4^{\text {th }}$ ed. Blackwell Publishing, Oxford.

Van Der Steen, L., B. Pardon, C. Sarre, B. Valgaeren, D. Van Hende, L. Vlamink, \& P. Deprez. 2014. Intestinal obstruction by Toxocara vitulorum in a calf. Vlaams Diergeneeskundig Tijdschrift 83:299-305.

Van Wyk, J.A. \& E. Mayhew. 2013. Morphological identification of parasitic nematode infective larvae of small ruminants and cattle: A practical lab guide. Onderstepoort J. Vet. Res. 80:46-60. https://doi.org/10.4102/ojvr.v80i1.539 